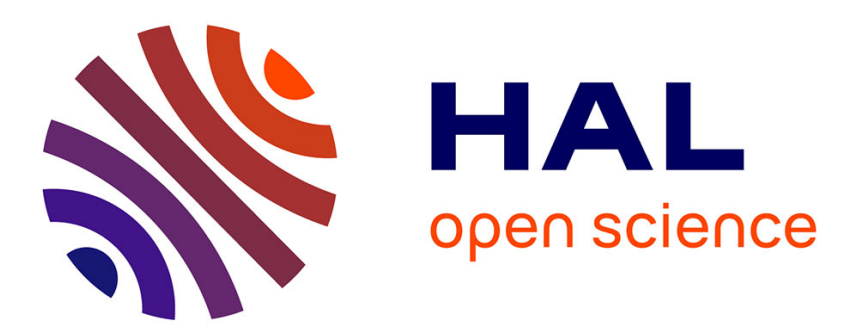

\title{
Integrating the Central European Past into a Common Narrative: the mobilizations around the 'crimes of Communism' in the European Parliament
}

\author{
Laure Neumayer
}

\section{To cite this version:}

Laure Neumayer. Integrating the Central European Past into a Common Narrative: the mobilizations around the 'crimes of Communism' in the European Parliament. Journal of Contemporary European Studies, 2015, Transnational Memory Politics in Europe: Interdisciplinary Approaches 23 (3), pp.344363. 10.1080/14782804.2014.1001825 . hal-01355450

\author{
HAL Id: hal-01355450 \\ https://hal.science/hal-01355450
}

Submitted on 23 Aug 2016

HAL is a multi-disciplinary open access archive for the deposit and dissemination of scientific research documents, whether they are published or not. The documents may come from teaching and research institutions in France or abroad, or from public or private research centers.
L'archive ouverte pluridisciplinaire HAL, est destinée au dépôt et à la diffusion de documents scientifiques de niveau recherche, publiés ou non, émanant des établissements d'enseignement et de recherche français ou étrangers, des laboratoires publics ou privés. 


\title{
Integrating the Central European Past into a Common Narrative: the mobilizations around the 'crimes of Communism' in the European Parliament
}

\author{
LAURE NEUMAYER
}

Université Paris 1 Panthéon Sorbonne and Institut Universitaire de France, France

\begin{abstract}
:
After the Cold War, a new constellation of actors entered transnational European assemblies. Their interpretation of European history, which was based on the equivalence of the two 'totalitarianisms', Stalinism and Nazism, directly challenged the prevailing Western European narrative constructed on the uniqueness of the Holocaust as the epitome of evil. This article focuses on the mobilizations of these memory entrepreneurs in the European Parliament in order to take into account the issue of agency in European memory politics. Drawing on a social and political analysis centered on institutionally embedded actors, a process-tracing analysis investigates the adoption of the furthest-reaching official expression of a 'totalitarian' interpretation of Communism to date: the Resolution on European Conscience and Totalitarianism from April 2009. This case study shows that the issue was put on the parliamentary agenda by a small group of Central and Eastern European politicians who had managed to 'learn the ropes' of effective advocacy in the Assembly. An official vision of Communism then emerged through intense negotiations structured by interwoven ideological and national lines of division. However, this narrative largely remains of regional, rather than pan-European, relevance. In the competition for the definition of 'Europe' and its values, the persistent diversity in the assessment of Communism gives evidence of the local rootedness of remembrance despite the pan-European ambitions of memory entrepreneurs.
\end{abstract}

KEY WORDS: Remembrance, European Union, Communism, European Parliament

Since the 1950s, the Council of Europe and the European Community/European Union have implemented a whole set of policies aimed at strengthening a hypothetical 'European identity' through the recollection of a common history and the promotion of shared values. The European political field is a complex configuration, composed of several interconnected but partially independent institutional arenas which produce a variety of public and official narratives about the past. The main institutional sources of these discourses are the Parliamentary Assembly of the Council of Europe (PACE), the European Parliament (EP), the EU Council and the European Commission. After the Cold War, a new constellation of actors has entered these arenas and upheld an interpretation of the history of Central and Eastern Europe based on the equivalence of the two 'totalitarianisms', Stalinism and Nazism. This vision challenged the core of the historical narrative that prevailed in Western European at the time: the uniqueness of the Holocaust as the epitome of evil (Mälksoo 2010; Pakier and Stråth 2010). 
This inflexion of the dominant institutional discourse is better understood when replaced in the longer evolutions of the narratives of 'the common past of Europe' produced by European institutions since their creation ${ }^{1}$ and in the academic and political debates on the 'singularity of the Holocaust' versus the 'totalitarian paradigm', Although its proponents present it as non-controversial, this reshaped official discourse on Communism is also the result of contentious negotiations within the European institutions, triggered by the mobilizations of a variety of political and social actors involved in a quest for 'memory adjustment' between the 'new' and the 'old' member states of the enlarged EU. These memory entrepreneurs (Pollak 2000) are positioned at different levels of government and circulate from one to another, while belonging to various social sectors: politics, academia, victims' associations and 'National Memory Institutes', MEPs have been particularly influential in this collective endeavor to frame a new historical narrative and have used their symbolic resources (reputation, knowledge, competence, prestige...) in a twofold way. First, they have implemented a wide range of awareness-raising activities such as parliamentary exhibitions, screening of documentary films, hearings and conferences. Second, they have engaged in legislative work to produce Declarations and Resolutions in which the boundaries of a 'legitimate' Europe-wide discourse on Communism have been renegotiated. Consequently, the current dominant parliamentary discourse is tilted towards a 'totalitarian' and 'crime-centered' representation of this ideology and of the political regimes that availed themselves of it ${ }^{4}$. It stresses the 'duty to remember' and urges to 'commemorate the victims' in a way which bears a close resemblance to the Holocaust template'.

Strikingly enough, these parliamentary memory entrepreneurs have been largely unexplored in the existing literature on the transnational politics of remembrance regarding Communism in Europe. Historical debates in the EP have been studied in order to compare it to PACE (Rostoks 2011), to analyze the case of the Holocaust (Waehrens 2011) or to investigate the institutional venues that are the most favorable to equating Communism and Stalinism (Littoz-Monnet 2013). While this literature often mentions the prominent role of post-communist politicians in constructing a post-Cold War discourse on Communism, its focus is usually restricted to the discourse itself. The actual mechanisms at play in this parliamentary work, which makes this Assembly a unique venue of transnational politics and policy-making, have so far been under-researched. The contention of this article is that it is necessary to meld discourse analysis with a sociological study of group mobilization, within

\footnotetext{
${ }^{1}$ See Calligaro in this special issue.

2 There are two intellectual origins to the comparison of Communist and Nazi crimes: the discussion on totalitarianism and the controversy surrounding the interpretation of German history. The concept of totalitarianism, which implies that Nazism and Communism have more common points than differences, was widely used in the early phase of the Cold War to discredit the Soviet bloc. It has been increasingly criticized for its analytical shortcomings and political bias in Western Europe from the 1970s onwards, but taken up at the time as a symbolic weapon by the democratic oppositions in the Eastern bloc. The Historikerstreit which opposed liberal and conservative German historians about the integration of Nazism in German history in 19861987 raised the issue of the uniqueness of the Holocaust versus the comparison with the crimes of Communism (Knowlton and Cates 1993). At the end of the 1990s, the Black Book of Communism again sparked hefty debates on totalitarianism and the assessment of Communism, both as an ideology and as the matrix of a distinct type of dictatorial regimes (Courtois et al. 1997; Rousso 1999).

${ }^{3}$ This generic term refers to the state-sponsored institutions established in Central and Eastern Europe to deal with the Communist past. Though their names and scopes of competence vary from country to country, they all conduct research and educational projects that contribute to building official narratives about Communism (Kopeček 2008).

4 This coarse perspective on dictatorship stresses the role of terror in the inception and persistence of the Communist regimes, thereby disregarding the social and political mechanisms (ideological appeal after Fascism or Nazism, social mobility, compromises between States and societies, etc) that may explain their evolutions over time and their longevity (Rousso 1999).

${ }^{5}$ See Büttner and Leidinger in this special issue.
} 
specific policy-making forums, in order to take fully into account the issue of agency in transnational "mnemopolitics" . Drawing on a social and political analysis of the EP focused on institutionally embedded actors, it theorizes agency as 'the ability to recognize and pursue individual interests, which varies according to the quality and types of resources held by social agents, pre-existing dispositions more or less adjusted to dominant norms in a context of interaction and finally the changes in the configurations and structures of power relations which create opportunities for a strategic reinterpretation of norms' (Rowell and Mangenot 2010,3). This actor-centered political sociology of European integration centers the scope of enquiry on the reconstruction of institutional and social spaces of action characterized by asymmetric power relations, thereby proposing new avenues to understand the differential capabilities to pursue strategic aims which transform existing collective norms.

In order to connect the parliamentary discourse on Communism to the institutional context of its elaboration, this article concentrates on the adoption of the furthest-reaching official expression of a 'totalitarian' interpretation of Communism to date: the 'Resolution on European Conscience and Totalitarianism' adopted by the EP on 2 April 2009 (hereinafter: 'the Resolution'). A process-tracing analysis confirmed by elite interviews ${ }^{7}$ looks first at the specific resources and legitimacy of strategic actors who successfully put this issue on the parliamentary agenda. It then turns to the institutional and argumentative strategies used by these actors to try to impose this cognitive frame, before assessing the outputs of their activities in terms of narrativization of Communism in the EU.

\section{Agenda-setting in the EP}

Since the end of the Cold War, European organizations have become venues where domestic conflicts over the past can be continued or amplified. The salience of the topic of 'Communist crimes' has gradually increased in transnational institutions after 2004, which paved the way for the uploading of some remembrance claims from domestic to European venues.

The national dynamics of attempts to condemn Communism need to be recalled to draw a full picture of the national/transnational nexus that underpins the European politics of remembrance. In the early 1990s, the assessment of the Socialist period has been constructed as one of the cleavages which structured the nascent democratic political fields in the former Eastern bloc. From the mid-1990s onwards, numerous anti-Communist circles have criticized the 'incomplete' character of the regime change which had, in their view, allowed former Communist leaders to maintain comfortable positions in society and to evade justice (Mark 2010). To a certain extent, the mounting pressures to manage the Communist past can also be interpreted as a reaction to the 'mnemonic accession criterion' imposed by the EU on its future member states. Giving greater visibility to the commemoration of the Holocaust and conducting a critical evaluation of collaboration with German SS and security police on the extermination of the Jewish population became one of the conditions which had to be met in order to join these organizations. In this context, anti-Communist activists set out to fight against the 'double standards' in the political, moral and legal judgment of Nazism and Stalinism. Although the legacies of Communism had been debated at PACE as early as 1992

\footnotetext{
${ }^{6}$ See the introduction to this special issue.

${ }^{7}$ Besides the final resolution the source material includes the motions for a resolution tabled by the political groups; the joint motions for a resolution that the groups agreed on; potential oral and written amendments; debates; explanations of votes; and votes. About 30 semi-structured interviews were also conducted with the relevant MEPs, their assistants and Parliament staff.
} 
(PACE 1992; PACE 1996), the enlargement of the EU to ten post-communist countries in 2004-2007 created new institutional venues to tear these claims out of their national frameworks. These memory entrepreneurs asked the EU to recognize more explicitly the sufferings endured by the 'other Europe' under Nazi occupation and Communism. In the literature, these demands have been analyzed as 'claims for recognition' (Closa Montero 2011) or attempts to set a 'Gulag memory' against a 'Shoah memory' (Droit 2007). Despite the indisputable 'politics of recognition' involved in these demands, these interpretations may suggest a binary opposition between 'Western' and 'Eastern' interpretations of the past, which would downplay the ideological dimension of the conflicting assessments of the former Communist regimes. Throughout the continent, European-level legitimization of the totalitarian interpretation of the communist past would indeed provide the Conservatives with a permanent symbolic advantage over the Left.

It is against this background that a gradual, albeit contentious, change in the official remembrance of Communism occurred across transnational political venues during the $6^{\text {th }}$ term of the EP (2004-2009). The numerous commemorations held during this period provided these entrepreneurs with a favorable political context ${ }^{8}$. However, the four milestones leading to the discussions on the Resolution illustrate the contentious logics of this agenda-setting.

First, the conservative European People's Party (EPP) adopted a Declaration in February 2004 which called for the EU to "adopt an official declaration for the international condemnation of totalitarian Communism' and invited 'the designation of a "Day of Victims" of the totalitarian Communist regimes' (EPP 2004). Because it proceeded from the right part of the political spectrum only, this Declaration had no direct official follow-up at the EU level.

Next, the EP adopted a Resolution on 'The Sixtieth Anniversary of the end of the Second World War on 8 May 1945'. Although its focus was pan-European, it pointed out that 'for some nations the end of World War II meant renewed tyranny inflicted by the Stalinist Soviet Union' (EP 2005). The issue of the comparison between Nazism and Stalinism was thus initially raised as part of a broader reflection on the Second World War and European integration. The debates on this text sparked controversy over the appropriate way to describe the fate of Eastern Europe after 1945 and the splits within the main parliamentary groups along national lines clearly showed the lack of common understanding of the war and of the Cold War in the Assembly (Neumayer, 2014).

Third, in January 2006 PACE adopted a Resolution on the 'International condemnation of the crimes committed by the Communist totalitarian regimes' (PACE 2006). However, this symbolically powerful document had no practical implications because it did not get the two third majority of votes that is required to proceed to the Committee of ministers ${ }^{9}$.

Finally, the EU Council reached an agreement in April 2007 regarding the Framework Decision on combating 'particularly serious forms of racism and xenophobia by means of criminal law', which allows member states to criminalize the public condoning, denial and gross trivialization of crimes 'directed against a group of persons defined by reference to race, color, religion, descent, or national or ethnic origins'. Lithuanian representatives, backed up by their Polish and Latvian counterparts, failed to convince the Council to enlarge this list of criteria to 'social status' or 'political convictions' in order to penalize the denial of

\footnotetext{
${ }^{8}$ The anniversaries of the end of the Second World War, the Budapest Uprising, the Prague Spring, the MolotovRibbentrop Pact and the fall of the Berlin Wall provided enabling conditions for the EU to reflect on the recent past. It did so by constructing a teleological narrative which presents European integration as the final outcome of all the struggles against tyranny during the XXth century.

9 The adoption of this Resolution cannot be analyzed in this article due to space limitation, but the official documents adopted by PACE and the EP in 2006 and 2009 were interwoven and mutually supporting.
} 
'Communist crimes' ${ }^{10}$. As a compromise, the Council asked the European Commission to organize a public hearing on 'crimes of genocide, crimes against humanity and war crimes committed by totalitarian regimes' (EU Council 2007). The Slovenian EU presidency organized this hearing in the EP on 8 April 2008. A small group of post-communist Conservative MEPs used this new opportunity structure to advance their claims during the Czech EU Presidency of January-June 2009, which coincided with the $20^{\text {th }}$ anniversary of the demise of Central and Eastern European Communist regimes.

These debates gave the 'newcomers' in the European Parliament the opportunity to build their parliamentary profile on historical issues. Yet, the EP is a specific institutional space defined by precise 'rules of the game' which structure power relations. Its members need to get a 'practical understanding' of those rules and the related institutional knowledge and know-how to accumulate 'European credit' and further their interests ${ }^{11}$. In addition, the EU constitutes a 'multileveled and polycentric political field' with a dual - national and supranational - power base, where actors typically try to transfer political resources from the national to the European level and back, to maximize their power. The relative strength of strategic actors in the debate on Communism therefore depended on both their institutional status and their social characteristics (Kauppi 2005, Georgakakis 2012).

The initiation of the Resolution resulted from the joint efforts of two types of memory entrepreneurs. The first group was composed of former dissidents who had occupied important national political positions before becoming MEPs. They used a position of moral authority and symbolic resources derived from their own life stories to raise awareness about the 'Communist crimes' in the Assembly. The four figures of the opposition to the Communist regimes who were particularly active in this field were Sandra Kalniete, from Latvia; Vytautas Landsbergis, from Lithuania; Tune Kelam, from Estonia; and László Tőkés, from Romania. Their direct experience of state repression had produced convergent 'totalitarian' representations of the Communist past ${ }^{12}$. Their previous political positions as heads of state (Landsbergis), diplomats (Kalniete) or long-time members of PACE (Kelam and Landsbergis) had also provided them with efficient resources in the EP: political negotiation skills at the national and international level; personal connections allowing for the activation of parliamentary, diplomatic and administrative networks. In addition, their

\footnotetext{
${ }^{10} \mathrm{EU}$ Treaties explicitly mention 'racism and xenophobia' as violations of the principles on which the EU is based, which provides a legal basis for European action. In criminal law, EU actions are however limited to 'serious trans-border crime' and to crimes that have already been recognized by international law. The scope of the Framework Decision is therefore restricted to 'crimes of genocide, crimes against humanity and war crimes as defined in Articles 6,7 and 8 of the Statute of the International Criminal Court [and in ...] Article 6 of the Charter of the International Military Tribunal appended to the London Agreement of 8 August 1945'. In addition, it states that 'since the Member States' cultural and legal traditions are, to some extent, different, particularly in this field, full harmonization of criminal laws is currently not possible' (European Council, 2007). Unanimous vote would be required at the EU Council to enlarge the list of crimes which can be tackled at the EU level. The lack of political will of some member states, the principle of subsidiarity and the possible tension between fighting radicalism and respecting free speech are the major obstacles to such an extension of EU action.

${ }^{11}$ Knowledge of abstract parliamentary procedures should be distinguished from know-how, defined as an ability to develop specific skills: establishing contacts with representatives of different countries, spotting key players and identifying political allies, and conceiving 'admissible arguments' framed in a 'general Europe perspective' as opposed to 'national' or 'ideological' positions (Beauvallet and Michon 2010, 2012). See (Hix and Lord 1997) and (Costa 2000) for additional analysis of the parliamentary work at the EP and the specific skills it involves. See also (Hurka and Kaeding 2012) on the relative marginalization of the EP's new members during the $6^{\text {th }}$ legislature.

${ }^{12}$ See for example the memoirs of two of these MEPs (Kalniete 2004; Landsbergis 2009). See also (Mark 2010) on the well-known controversy between Sandra Kalniete and the Vice-President of the Central Council of Jews in Germany at the Leipzig Book Fair in 2004.
} 
parliamentary specialization as 'defenders of human rights ${ }^{13}$ was instrumental in framing their cause as a universal human rights issue. These biographical characteristics were further strengthened by important institutional positions, such as vice-Presidency of the EP (Tökés) or membership in the EPP Bureau (Landsbergis).

\section{Historical figures of the opposition to Communism}

* Sandra Kalniete (LV): born in relegation in Siberia in 1952, art historian. One of the leaders of the Latvian popular front (1989-1991), diplomat (ambassador to the UNESCO, ambassador to France, Foreign Affairs minister 2002-2004). Member of the Convention for the Future of Europe, European commissioner (2004), MEP (2009-).

*Vytautas Landsbergis (LT): born in 1932, musicologist. President of the Council of the Sajudis movement (1988-91), President of Lithuania (1990-1992), member of PACE (1993-96, 2000-02), MEP (2004-2014).

* László Tökés (RO): born in 1952, bishop. Leader of the 1989 demonstrations in Timisoara. MEP (2007-), vice-president of the EP (June 2010- January 2012).

*Tunne Kelam (EE): born in 1936, archivist and historian. One of the leaders of the independence movements in Estonia, member of the Estonian Committee (1990-1992) and of the Estonian Parliament (1992-2004). Member of PACE (1992-2000), MEP (2004-).

The second type of memory entrepreneurs presented different properties: they were a bit younger, lacked the symbolic authority obtained in dissident activities but were closely linked to the EPP leadership and to national governments. Alongside Tunne Kelam, two of these MEPs initiated the parliamentary process leading to the adoption of the Resolution. The first one was József Szájer, from Hungary, who had been one of the founding members of the FIDESz right-wing party and served as vice-president of the EPP Group. The second one, Jana Hybášková, had close ties to the political and administrative leadership of the Czech EU Presidency. She acted as the channel through which a group of Czech social and political actors sought to give a European dimension to a controversial narrative of Communism centered on its 'criminal nature'.

\section{The 'Young Turks' of anti-Communism}

*Jana Hybašková (CZ): born in 1956, PhD in philosophy in 1989, diplomatic career, MEP (2004-09). Member (2004-08) and President (2008-10) of the Democratic European Party. EU Ambassador to Irak (2011-).

*József Szájer (HU): born in 1961, lawyer, one of the founding members of FIDESZ. EU-related career before 2004: President of the European Affairs Committee of the Hungarian Parliament, Observer at the EP, member of the Convention for the Future of Europe. MEP (2004-) and vicepresident of the EPP Group.

\footnotetext{
${ }^{13}$ This specialization derives from their parliamentary activity: membership in commissions, drafting of reports, questions, declarations and motions for resolution.
} 
A classic mechanism of uploading, that is a transfer of claims to the European level, then occurred through the so-called 'Prague Process' ${ }^{14}$. After a protracted political and academic struggle, an Institute of National Memory called 'Institute for the Study of Totalitarian Regimes' (ISTR) had been created in 2007 in the Czech Republic. In order to establish its legitimacy in a very polarized national context, this Institute organized a conference on 'European Conscience and Communism' in Prague in June 2008, with the help of Hybášková and the support of the Foreign Affairs Minister Alexander Vondra ${ }^{15}$. The 'Prague Declaration on European Conscience and Totalitarianism' adopted during this conference was later signed by prominent former dissidents such as Václav Havel, Joachim Gauck and Vytautas Landsbergis, alongside 50 MEPs, members of PACE, human rights activists, historians and staff of several Institutes of National Memory.

This Declaration demanded that the moral, political and legal treatment of Communism be placed on a par with that of Nazism. Although its first point stated that 'both the Nazi and the Communist totalitarian regimes [should] each be judged by their own terrible merits', the rest of the text only emphasized the 'substantial similarities' between these regimes because of their constant use of terror. It underlined, for example, that 'exterminating and deporting whole nations and groups of population' were indivisible parts of the ideologies they availed themselves with. Though it did not refer to the concept of genocide, the Declaration called for a qualification of 'the many crimes committed in the name of Communism' as 'crimes against humanity' and for the 'introduction of legislation that would enable courts of law to judge and sentence perpetrators of Communist crimes and to compensate victims of Communism'. On a symbolic level, the parallel with Nazism justified establishing ' 23 August, the day of signing of the [...] Molotov-Ribbentrop Pact, as a day of remembrance of the victims of both Nazi and Communist totalitarian regimes, in the same way Europe remembers the victims of the Holocaust on 27 January'. Finally, the Declaration suggested the creation of an 'Institute of European Memory and Conscience which would be both [...] a European research institute for totalitarianism studies [and] a pan-European museum/memorial of victims of all totalitarian regimes' (Prague Declaration 2008).

A first alignment of interest of actors situated in different political and administrative fields occurred in the EP on 18 March 2009, when the Czech presidency organized a hearing on 'European Conscience and the Crimes of Totalitarian Communism: Twenty Years After' with the help of the Slovak Commissioner for Culture Jan Figel' and of some signatories of the Prague Declaration (Kelam, Kalniete, Tökés, Landsbergis and Szájer). On 2 April 2009, a direct outcome of the 'Prague process' was the adoption a parliamentary Resolution which took over most of the Prague Declaration.

\section{Institutional and argumentative strategies}

The adoption of the Resolution illustrates a successful socialization of newcomers, who managed to assimilate the parliamentary rules of interaction - and especially a capacity

\footnotetext{
${ }^{14}$ Literature on 'uploading' has demonstrated that even 'soft' EU policy instruments such as an EP Resolution can constitute important symbolic and strategic gains for domestic actors and provide sufficient motivation for seeking to involve the European level. Batory has shown, in a case study on the Hungarian media law controversy, that 'uploading issues to the EP arenas is likely to be rewarding for national political actors who are in a weak position in their member state, have an image and values compatible with involving EU institutions in a given conflict, and resources that enable them to form a winning coalition at the European level in a debate they would stand to lose at home' (Batory 2014: 234).

${ }^{15}$ Former dissident, close to Václav Havel, who led the Czech EU Presidency in 2009.
} 
to overcome national and ideological divisions and to reach a political compromise between the two largest political groups in the EP, the EPP and the PES (Party of European Socialists).

They afore-mentioned EPP memory entrepreneurs had to adjust their strategies to a changing configuration of actors involved in the debate on totalitarianism.

In the run up to the parliamentary hearing of April 2008 the second largest group in the EP, the PES, had created a 'Working Group on History' in order to 'invite the EU to act against any attempt to rewrite history' (PES 2009a). This Working Group, headed by the Dutch MEP Jan Marinus Wiersma, included 3 'newcomers' with very different life trajectories, who had actively opposed the Communist regime (József Pinior, from Poland), served this regime (Justas Paleckis, from Lithuania) or left the country (Libor Rouček, from the Czech Republic). Prominent MEPs from older member states also belonged to this Group: the PES German president (Martin Schulz) and one of its vice-presidents (the Austrian Hannes Swoboda), alongside Miguel Angel Martinez Martinez, a Spanish former exile under Franco. In order to avoid the public disagreements which had occurred in 2005, this rather heterogeneous group defined the PES official line during the negotiations on the Resolution in March-April 2009.

\section{PES 'Working Group on History'}

*Józef Pinior (PL): born in 1955, Solidarność leader, political scientist. MEP (2004-2009).

*Libor Rouček (CZ): born in 1954, left the country in 1978. Political scientist. EU-related career before 2004 (Vice-Chair of the Committee for European Integration, Czech Parliament; head of the ČSSD observers' delegation to the EP). MEP (2004-2014). At the EP: head of the ČSSD delegation (2004-2009); First Vice-Chair of the Foreign Affairs Committee (2006-2009). Vice-President, PES Group (2009-2012).

* Justas Paleckis (LT): born in 1942. Journalistic, diplomatic and administrative career before 1990. Vice-Chair of the Committee on Foreign Affairs, Lithuanian Parliament (1990-1992). Foreign policy advisor to the Lithuanian President (1993-1996). Ambassador of Lithuania to the UK (1996-2001). Deputy Foreign Minister of Lithuania (2002-2004). MEP (2004-2014).

*Jan-Marinus Wiersma (NL): born in 1951. Studied History. Political advisor at the Foreign Policy Parliamentary Group of the Dutch Labour Party in the National Parliament (1978-1987). International Secretary and $2^{\text {nd }}$ vice-president of the Dutch Labour Party (1987-1999). Vice-President, PES Group (1999-2004). MEP (1994-2009).

*Hannes Swoboda (AT): born in 1946. Studied Law and Economics. Career in the SPÖ. MEP (1996). Vice-Chairman, PES Group (1997-2012). Chairman, PES Group (2012-2014).

*Martin Schulz (DE): born in 1955. Bookseller and publisher. Career in the SPD. MEP (1994-): PES Group Coordinator, Subcommittee on Human Rights (1994-1996); PES Group Coordinator, Committee on Civil Liberties and Home Affairs (1996-2000); chair, PES group (2000-2012); President of the EP (2012-).

*Helmut Kuhne (DE): born on in 1949. Sociologist. MEP (1994-2009).

*Miguel Angel Martinez Martinez (ES): born in 1940. Opposition student leader under Franco, then in exile in France. Vice-President (1983-1992) and President (1992-1996) of PACE. MEP (19992014). Member of the Board of Trustees of the House of European History (2011-...).

This parliamentary debate emerged forcefully because the anti-Communist mobilizations cut across existing lines of division within the Assembly, along national 
('newcomers' versus 'older' member states) as well as ideological lines (right-wing versus left-wing political groups). The Conservatives, backed by the Liberals and the Greens, opposed the Socialists while the far-left refused to join the debates. But a closer look at the records of parliamentary debates gives evidence of splits within political groups. Though the left-wing groups were particularly prone to internal tensions regarding the nature of Communism and the relevance of the concept of 'totalitarianism', the various conservative sensibilities also held slightly different views on how to manage the legacies of the Communist regimes. Likewise, national cleavages should not be interpreted as a binary East/West division: some national delegations showed very specific voting patterns linked to distinct historical sensibilities ${ }^{16}$. In addition, some Euroskeptic MEPs objected to the Resolution because of its praise of European integration, and not because they disagreed with its interpretation of Communism (EP 2009b). The discussions on the content and wording of the Resolution ${ }^{17}$ defined the boundaries of a new, post-Cold War, legitimate discourse on the Communist past in the EP.

Two issues proved the most controversial during the parliamentary debate organized on March $25^{\text {th }}, 2009$. The first one dealt with the potential existence of a single legitimate regime of remembrance in Europe: should the EP, or the EU as a whole, promote one vision or multiple perspectives on historical events? Can a Europe-wide memory of victimhood be established?

One side of the argument held that it was necessary to process the past thoroughly in order to draw lessons from it. This is how Alexander Vondra explained the support of the Czech EU Presidency to the EU debate on 'Communist totalitarianism':

Only by reconciling ourselves to history can we truly break away from the bonds imposed by the regimes of the past. Secondly, it is only by appreciating fully the suffering brought about by such regimes that we can fully understand the present. The European Union stands for everything that is the opposite of totalitarianism. For those of us who emerged from the grip of Communism, membership of the European Union is one of the main guarantees that we will never again revert to totalitarianism. This is a guarantee which we all share. It is something to be valued and never taken lightly. [...] Thirdly, we owe it for the sake of our children. There are lessons to be learnt from our totalitarian past. Perhaps most important of these is the need for respect for human rights and fundamental values.

In addition, some MEPs highlighted that there can be no true integration of Europe without, in Tunne Kelam's words, the 'integration of European historic perception':

I think that today what we need is not only the economic and political enlargement of Europe but the enlargement of European awareness of the massive crimes against humanity which occurred everywhere in Europe in the 20th century. We need the integration of European historic perception - the integration of prejudices and different views of history - as only in this way can we proceed to the better Europe of the future.

This was supported by Hybášková's statement for the EPP, which called for common action between 'East and West' on their 'shared history':

\footnotetext{
${ }^{16}$ Due to the role of the Communists during the civil war and the fight against the military regime in the $1960 \mathrm{~s}-$ 70s, there are strong resistances to equalizing Nazism and Communism in Greece for example. Ten out of the 11 Greek MEPs from the EPP abstained from voting on the Resolution. No other EPP member abstained.

17 Parliamentary Resolutions are adopted on the initiative of one or more individual members. Initially the political groups table a motion for a resolution. Then they usually agree on a joint motion for a resolution which is debated in the plenary assembly. Finally the resolution is put to the vote and adopted by way of simple majority.
} 
In 2005 we adopted a resolution on the 60th anniversary of the end of the Second World War. We discovered that the European Parliament and the EU lacked the political will to pursue a common understanding and evaluation of European history. While the victims of Fascism and Nazism have received decent compensation, millions of victims of Communism have been forgotten. I am therefore delighted to announce that the resolution on the European Conscience and Totalitarianism, on which most political families in this house have been working this afternoon, is almost ready. Europe will not be united as long as West and East do not agree to joint studies, recognition, dialogue and understanding of the shared history of Fascism, Communism and Nazism.

The counter-argument stressed that this debate may lead to the instrumentalization of history, as stated by Jan Marinus Wiersma, speaking for the PES:

My group is not against the debate that is being held today per se, but we do have a great deal of difficulty with summarizing the result of this debate in a resolution. It gives the impression that we can lay down in a resolution how we should deal with Europe's history, and specifically with the totalitarian past. [...] As politicians, we have a responsibility when it comes to organizing what it is that we want to commemorate specially, but let us do that in collaboration with historians.

The rejection of a 'politically biased' discussion was expressed in a more radical way by the Greek member Athanasios Pafilis, from the far left GUE (European United Left) group:

The escalation in the European Union's wretched anti-Communist strategy is a brazen insult to the people: with the counterfeiting of history, slander and lies, Fascism is being equated with Communism. The most reactionary and barbaric regime to which capitalism gave birth, namely Fascism, is being equated with the most progressive idea conceived by man, namely Communism and the abolition of the exploitation of man by man. It is an insult to the memory of twenty million Soviets who sacrificed their lives to conquer Fascism. This vulgar antiCommunism is targeted not so much at the past; it is targeted mainly at the present and at the future.

The second widely debated topic was related to the comparison of Communism and Nazism: are Nazism and Communism 'equally criminal' both as ideologies and as historically existing regimes? Should Communism, as an ideology, be distinguished from Stalinism, as a political regime ${ }^{18}$

József Szájer expressed the position of one group of MEPs who stressed the structural similarities between Nazism and Communism, in spite of their ideological differences:

A democrat, a European cannot accept the fact that even today, even in this Parliament, there are people for whom the crimes of the Communist dictatorship are excusable and forgivable. A double standard distinguishing between victim and victim, crime and crime, suffering and suffering, death and death, is unacceptable. Those who try to justify the crimes of Communist dictatorship argue that all those horrors were committed by those regimes in the name of noble ideals, in the name of equality and fraternity. Ladies and gentlemen, Madam President, this is an enormous lie, and all they have done is to be counted not in their favor but against them, for it was with the promise of noble aims that they deceived people.

\footnotetext{
${ }^{18}$ See (Leggewie 2008) and (Kattago 2009) for a scientific discussion of these complex issues.
} 
Likewise, László Tökés underlined the 'double standards' in the management of the Communist and the Nazi legacies:

The European Community must abandon the double standard that is evident in the different ways in which Nazism and Communism have been judged. Both inhumane dictatorships deserve equal condemnation. I ask the European Parliament to stand in solidarity with the victims of Fascist Communism and to help defeat the enduring legacy of Communism in accordance with the aforementioned moral, historical and political exigencies. Only in this way can a divided Europe be truly unified.

On the other hand, some MEPs like the GUE member Vladimir Remek interpreted the condemnation of Communist crimes as an attempt to disqualify the Communist ideology as a whole:

I am not blind of course and under so-called Communism there was repression, injustice and coercion. Yes, it is necessary to investigate and justly condemn the crimes. Yet [...] if someone does not want to see the difference between Communism and Nazism, between Communists in the past and Communists in the present, who like myself represent significant numbers of Communist voters here in Parliament after democratic elections, then they are perhaps simply trying to lump me together with the Nazis.

In order to break away from this comparison, the Polish PES member Józef Pinior suggested taking other dictatorships into account when discussing the common European past:

The Europe of today should remember the victims of 20th-century totalitarian regimes worldwide. Those victims are today the foundation of our memory, the lasting spiritual basis of European democracy. At the same time we see the entire history of the 20th century. We remember the victims of authoritarian systems, the victims in European countries, in nationalistic and militaristic regimes, in Spain, in Portugal and in Greece.

After this first debate, the negotiations of the Resolution involved four consecutive steps leading to a compromise between the two biggest parliamentary groups. Hybášková, Kelam and Szájer first tabled a motion for the EPP on 25 March 2009, which reiterated the claims of the Prague Declaration (EPP 2009).

The same day, the PES Working Group on History tabled its own motion for a very different, and much shorter, Resolution. The Socialists expressed a strong disinclination for politicians to tackle history: they cautioned against 'misinterpretations of history', underlined that 'objective historical narratives do not exist' and recalled that 'the $20^{\text {th }}$ century history of Europe [was] very complex and ambivalent, as [were] people's memories of it'. Regarding Communism, substantial differences distinguished the PES proposal from the EPP one.

The Socialist motion refrained from using the expression 'totalitarian Communist regimes' and mentioned instead 'authoritarian and totalitarian regimes' or 'dictatorships', thereby not singling out 'Nazism and Communism' as the last century's ultimate evils. Second, the motion emphasized that the specific historical legacy of the new member states should be taken into account. It pictured Nazism as the primary memory in Europe, with Communism seen as an addition: "whereas the dominant historical experience of Western Europe was Nazism, whereas the countries of Central Europe had added the experience of Communism, and whereas understanding has to be promoted for these countries' double legacy of dictatorship'. 
The PES likewise upheld a nuanced view on the equivalence between Communism and Nazism, by comparing Nazism with Stalinism, and not with Communism as such: 'most historians agree that Nazism and Stalinism were essentially different, despite certain similarities, although from the perspective of the victims it makes no difference which regime deprived them of their liberty or tortured or murdered them for whichever reason'. Disregarding legal arguments, the only concrete action called for by the PES was of a commemorative nature: 'the proclamation of a European-wide Remembrance Day for the victims of all totalitarian regimes, especially Nazism and Stalinism, to be celebrated with dignity and impartiality' (PES 2009b).

The following day, three other political groups - the Conservative 'Union for Europe of the Nations' (UEN), the Liberal ALDE (Alliance for Liberals and Democrats for Europe) and the Greens, reacted with their own motion for a resolution which was tabled in each case by mostly post-Communist MEPs. These motions asked for more or less radical measures to manage the legacies of the Communist regimes: support to historical research, creation of an international Court of law, proclamation of a day to commemorate the victims of totalitarian regimes, etc. By contrast, the GUE and the Euroskeptic 'Independents/Democrats' (IND/DEM) did not table their own motion and refused to participate in the discussions.

The EPP, the UEN, the Liberals and the Greens finally tabled a joint motion for resolution on 30 March 2009, which the PES refused to join although it had taken over most of its own document. This tactic put the Socialists in a better position to impose almost all their amendments during the plenary session of the EP on 2 April 2009: although a simple majority is technically sufficient to adopt a Resolution, it would have been politically impossible for the EP not to reach an overwhelming majority on such a symbolically loaded text.

8 out of the eleven PES amendments were indeed adopted during the plenary session. As a result, the Resolution's final version started with several recitals warning against 'political instrumentalization of history'. Rather than focusing only on Nazism and Stalinism, it included the Southern European dictatorships from Spain, Greece and Portugal in the common European past. The text also distinguished Stalinism from Communism and replaced the wording 'Communism, Nazism and Fascism' with 'Nazism, Stalinism and the Fascist and Communist regimes' when describing the pan-European historical legacy. The Resolution played down the importance of Soviet Communism by mentioning the human rights violations committed by 'all the totalitarian and authoritarian regimes' instead of singling out 'totalitarian Communist regimes'. Finally, its recital $G$ mentioned 'the uniqueness of the Holocaust', which had been included in the initial motions of the Liberals and the Greens only. Although the unprecedented character of the extermination of the Jewish people by the Nazis was duly noted, its importance was greatly reduced compared to the Resolution on the end of the Second World War adopted in 2005 (EP, 2005).

However, three of the PES amendments were voted down or orally amended during the plenary session. The amendment which portrayed Communism as 'an addition' to Nazism was rephrased in the following way: 'the Central European countries have experienced both Communism and Nazism'. In this version, Soviet Communism (as a whole) is implicitly placed on the same footing as Nazism. Second, the call to create a 'professional academic network to enhance cooperation among national research institutes' instead of the 'Platform of European memory and Conscience' already mentioned in the Prague Declaration, was dropped. Third, the EP rejected the suggestion that historians should be consulted when choosing a date to commemorate the victims of 'all totalitarian and authoritarian regimes', instead of having politicians decide on 23 August (EP 2009). 
This EPP-PES compromise, which barely preserved the historical specificity of the Holocaust while insisting on the crimes of Communism, paved the way for the adoption of the Resolution with an overwhelming majority.

Among the 632 MEPs who participated in the vote ( $80 \%$ of the total number of seats), 554 voted in favor of the Resolution (87\% of votes), 44 against (7\% of votes) and 33 abstained ( $5 \%$ of votes). In terms of participation to the vote, the most active MEPs were from the Greens (88\% of the group members), the UEN (86\%), the Liberals $(85 \%)$ and the EPP (85\%). About three quarters of the PES members (77\%) and half of the Independents-Democrats $(50 \%)$ voted on the resolution. By way of contrast, only $29 \%$ of the GUE members and $6.9 \%$ of the Non-Affiliated voted on the text.

As regards the proportion of positive votes, the groups which were the most favorable to the Resolution were the ALDE (85\% of the group's votes), the UEN (84\%), the Greens $(83 \%)$ and the EPP (81\%). $63 \%$ of the PES members approved the Resolution, alongside $53 \%$ of the Non-Affiliated and only $18 \%$ of the Independents-Democrats. Again, the GUE was particularly critical of the Resolution, which was approved by one of its member only ${ }^{19}$.

\begin{tabular}{|c|c|c|c|c|c|}
\hline Political Group & Seats & $\begin{array}{c}\text { Vote for } \\
\text { (\% of the } \\
\text { group's seats) }\end{array}$ & $\begin{array}{l}\text { Vote against } \\
\text { (\% of the } \\
\text { group's seats) }\end{array}$ & $\begin{array}{c}\text { Abstention } \\
\text { (\% of the } \\
\text { group's seats) }\end{array}$ & $\begin{array}{c}\text { Participation to } \\
\text { the vote } \\
\text { (\% of the } \\
\text { group's seats) }\end{array}$ \\
\hline EPP & 288 & $235(81.59 \%)$ & 0 & $10(3.47 \%)$ & $85 \%$ \\
\hline PES & 217 & $137(63.13 \%)$ & $31(9.01 \%)$ & 0 & $77.4 \%$ \\
\hline ALDE & 100 & $85(85 \%)$ & 0 & 0 & $85 \%$ \\
\hline UEN & 44 & $37(84.09 \%)$ & 0 & $1(2.27 \%)$ & $86.3 \%$ \\
\hline $\begin{array}{l}\text { Greens/European } \\
\text { Free Alliance }\end{array}$ & 43 & $36(83.72 \%)$ & $1(2.32 \%)$ & $1(2.32 \%)$ & $88.3 \%$ \\
\hline GUE-NGL & 41 & $1(2.43 \%)$ & $7(17.07 \%)$ & $4(9.75 \%)$ & $29.2 \%$ \\
\hline IND/DEM & 22 & $7(18.18 \%)$ & $1(4.54 \%)$ & $3(13.63 \%)$ & $50 \%$ \\
\hline Non-Affiliated & 30 & $16(53.33 \%)$ & $5(16.66 \%)$ & $2(6.66 \%)$ & $75.69 \%$ \\
\hline Total EP & 785 & $554(70.57 \% *)$ & $45(5.73 \% *)$ & $33(4.20 \% *)$ & $80.5 \% *$ \\
\hline
\end{tabular}

\section{Ambiguous Outputs: Narrating Communism in the EU}

Memory entrepreneurs in the EP have created analytical categories ('totalitarian crimes', 'Communist crimes') and figures ('victims of Communist crimes', 'heroes of the anti-totalitarian resistance'), which they strive to impose in all public discussions of the

\footnotetext{
${ }^{19}$ The Dutch MEP Erik Meijer.
} 
Communist past of Central and Eastern Europe. These figures and categories justify their demands of proof (opening of the archives), recognition (symbolic declarations and commemorative actions) and retribution (trials of perpetrators) (Fassin and Rechtman 2007). Although it mentions the uniqueness of the Holocaust and warns against politicization of history, the Resolution illustrates an undisputable discursive shift towards an interpretation of Communism centered on its criminal nature and its structural proximity to Nazism. Ambiguity prevails however regarding the practical consequences of this symbolic association of dictatorships, both within and outside the EP.

Inside the Parliament, the Resolution represents the main symbolic weapon of antiCommunist MEPs. In 2010, some of them formed an informal grouping called 'Reconciliation of European histories' (REH), which was primarily led until 2014 by Kalniete, Landsbergis, Kelam and Tökés. Contrary to the 'multi perspective history' promoted by European institutions (Garcia 2009), REH defined its aim as the establishment of a single 'historical truth' at the EU level: 'true reunification of European history based on truth and remembrance. We have to continue work on converging the views of all Europe about the history of the 20th century. [...] We aspire to develop a common approach regarding crimes of totalitarian regimes, inter alia totalitarian communist regime of the USSR, to ensure continuity of the process of evaluation of totalitarian crimes and equal treatment and non-discrimination of victims of all totalitarian regimes ${ }^{20}$. Its main activities consisted in adopting common declarations and in organizing conferences to discuss 'Communist crimes' and their legacies. However, REH was not recognized as an official Intergroup in the EP and its reach was restricted to a narrow parliamentary segment: the post-Communist political right. Out of its 40 official members in 2010-14, 32 came from a 'new' member state and 33 belonged to the EPP. This signaled a failure to engage with MEPs who did not share both a direct experience of Communism and Conservative political orientations.

A similar lack of conclusiveness characterizes the three direct outcomes of the Resolution outside the EP. Legal debates, the establishment of a Day of Remembrance and the creation of an international research center/memorial have fallen short of the memory's entrepreneurs' projects.

No development occurred in the legal sphere, which was only mentioned in the Resolution by a vague commitment to 'support strengthened international justice'. The symbolic equalization of Nazism and Communism failed to produce the effects called for in the Prague Declaration: the European Commission rejected the suggestions made in various institutional arenas to penalize Communist crimes and bring perpetrators to justice, and the EU Council went along with the Commission's position.

After the hefty debates on the penalization of the denial of 'Communist crimes' which took place in the EU Council in 2007, the Commission was invited to 'examine and to report to the Council within two years after the entry into force of the Framework Decision, whether an additional instrument is needed, to cover publicly condoning, denying or grossly trivializing crimes of genocide, crimes against humanity and war crimes directed against a group of persons defined by other criteria than race, color, religion, descent or national or ethnic origin such as social status or political convictions' (European Council 2007b: 25). The Commission requested an expert study to be submitted in January 2010, which provided a comparative analysis on 'how the memory of crimes committed by totalitarian regimes in Europe is dealt with in the Member States' (Closa Montero, 2010). This comprehensive comparison was decided by the Commission in order to depoliticize the issue of Communist crimes by 'diluting' it in a broader reflection on the management of non-democratic pasts throughout the

\footnotetext{
${ }^{20}$ http://eureconciliation.wordpress.com/about/
} 
continent $^{21}$. In December 2010, a few days before the Commission's report was due, six Foreign ministers from the former Eastern bloc $^{22}$ wrote an official letter to the European justice commissioner, calling for communist crimes to be 'treated according to the same standards' as those of Nazi regimes, notably in those countries with Holocaust denial laws. The European Commission, however, relied on the expert study to confirm that the legal conditions for adopting an additional instrument at EU level were not met, because the denial of Communist crimes is absent in the national legislation of most EU member states ${ }^{23}$ (European Commission 2010).

Likewise, the calls for the creation of an International Court which would have its seat in the EU and try crimes against humanity have not led to any practical measures. Besides the lack of EU competences, there are additional legal obstacles to the creation of an International Court: it would be necessary to prove that there are obstacles at the national level to the proper trial of these crimes and that all other international legal venues, such as the European Court of Human Rights, have been used in vain ${ }^{24}$.

Second, 23 August was indeed established as 'day of Remembrance for the victims of all totalitarian and authoritarian regimes' in the EU but failed to gain the same symbolic significance as 27 January, the day when Holocaust victims are officially mourned throughout the continent. Although the EU Justice Commissioner makes a speech on 23 August, official commemorations are organized on a large scale only in the Baltic states, which were directly affected by the Molotov-Ribbentrop Pact. In these countries, the memory of national suffering under Soviet and Nazi occupation tends to occlude the centrality of the Holocaust and the domestic mnemonic landscape is particularly polarized (Kattago, 2009).

The third direct impact of the Resolution has been the creation of Platform for European Memory and Conscience. This network was set up to stabilize the links between the afore-mentioned four MEPS from the REH group (who belong to its Board of Trustees), Institutes of National Memory and like-minded sectors of academia who endow the 'totalitarian' narrative with scholarly authority ${ }^{25}$. The Platform representatives systematically underline that it draws its legitimacy from the EP Resolution. It is however a markedly Central and Eastern European endeavor: its creation was strongly supported by the Czech authorities, the ISTR hosts its logistical center in Prague and its Representatives come from the former Eastern bloc only. Although the European Commission financially supported its two flagship projects in 2013 (a reader for high school students untitled Lest we forget: Memory of Totalitarianism in Europe and a travelling exhibition on 'Totalitarianism in Europe'), the Platform never received operational support for its activities. To date, its lobbying activities aimed at increasing the share of financial support for projects related to Stalinism in the program 'Europe for citizens' and to take legal steps to prosecute the crimes against humanity perpetrated during the Communist period have been unsuccessful. Moreover, the Platform's intention to create a European museum of totalitarianism in Brussels which would also serve as a memorial for the victims, has failed to materialize.

The limited impact of the Resolution underlines the importance of the global context, but also of the constraints stemming from the institutional venues in which these remembrance claims are expressed.

\footnotetext{
${ }^{21}$ Interviews, European Commission, January 2014.

${ }^{22}$ From Lithuania, Latvia, Hungary, the Czech Republic, Romania and Bulgaria.

${ }^{23}$ With the exception of Lithuania, Latvia, Hungary, the Czech Republic and Poland.

${ }^{24}$ Interviews, European Commission, January 2014.

${ }^{25}$ The only historian who belongs to its Board of Trustees is Stéphane Courtois, editor of the Black Book of Communism.
} 
Requests for a Europe-wide condemnation of 'Communist crimes' have been justified by moral and legal arguments linked to emerging global norms such as the universalization of the figure of the 'victim', the 'globalization' of the Holocaust and the tendency to handle painful pasts in courts of law. Attempts to align on the paradigmatic example of the Holocaust have nevertheless met with outrage from several left-wing movements and Jewish organizations. Some of them have interpreted these remembrance claims as thinly veiled attempts to 'trivialize the Holocaust' while mitigating East Europeans' own complicity in the extermination of the Jewish population ${ }^{26}$. This confirms that the Holocaust does remain the 'negative founding myth for Europe' after the end of the Cold War (Leggewie 2008: 219), whereas the 'Velvet Revolutions' of 1989 have failed to symbolize the beginning of a new era for the whole continent.

According to Kattago, three factors account for the particular status of the Holocaust in transnational remembrance policy, the main ones being the assumption of the extermination of the Jews as an unprecedented, singular event, and the fact that their systematic killing occurred in both Eastern and Western parts of Europe. Moreover, Communism ended peacefully, without any official recognition of the crimes committed in the name of the Soviet Union, whereas the Nuremberg Trials established the important precedent of crimes against humanity and paved the way for the codification of human rights in international law. Third, anti-Communist memory entrepreneurs represent just one side of the debate between 'a politics of memory emphasizing the specificity of culture in national narratives' on the one hand, and on the other hand a perspective which claims that Communism must be assessed on the basis of universal norms and values, in order to solve 'the tension between unique culture and shared humanity' (Kattago 2009: 375).

This structural tension between universal values and particular historical experiences is extremely strong in the EU as well, which provides memory entrepreneurs with specific constraints. To be considered as a legitimate player in the European game, MEPs need to 'denationalize' their cause and underline the 'European' relevance of their claims. Yet many of the anti-Communist memory entrepreneurs rely primarily on a 'biographical' legitimacy linked to the figure of the 'witness-victim'. This provides them with moral authority but makes it difficult to 'rise above national idiosyncracies' and represent 'the general European interest'. The legacy of the West European Left also partly accounts for their difficulty to reach out to older member states, as for many of its representatives Communism is both a viable ideology and a political party within European parliamentary democracy.

Faced with these constraints, anti-Communist entrepreneurs have developed ambiguous repertoires in a search for a balance between 'humanitarian-oriented' and 'conflict-oriented' framing when assessing Communism. The former stresses 'compassion for the victims of human rights violations' while underlining their innocence and the injustice they suffered - which leads to a certain de-politicization of the cause. The latter, by contrast, relies on the terminology of 'heroes' and 'martyrs' and underlines the active fight of a given political camp against state terror. The reference to human rights and the category of victim, while giving the cause a broader significance, tends to erase this combative dimension. The combination of these repertoires underlines a central challenge faced by these memory

\footnotetext{
26 The Prague Declaration and the 2009 EP Resolution prompted Shimon Samuels, the Simon Wiesenthal Centre's Chief Delegate and Director for International Relations, to send a statement to the OSCE in which he condemned 'a Project to Delete the Holocaust from European History': http://www.wiesenthal.com/site/apps/s/content.asp?c=lsKWLbPJLnF\&b=4442915\&ct=7548759\#.VHXAF c90zIU (accessed December $1^{\text {st }}$ 2014). The American-born scholar and activist Dovid Katz provides another example with his long-lasting campaign against what he calls 'the obfuscation of the Holocaust': http://defendinghistory.com/ (accessed December $\left.1^{\text {st }} 2014\right)$.
} 
entrepreneurs in their struggle for a Europe-wide historical narrative: respecting the normative constraints imposed by global norms and European institutions, while achieving recognition of Central and Eastern European particular historical legacies.

\section{Concluding remarks}

This article has argued that a process-tracing analysis centered on institutionally situated actors makes new inroads in the study of memory politics and policy-making in Europe. It provides an alternative to essentialist or normative conceptions of transnational mnemopolitics which tend to overlook the crucial issue of agency in the struggles over the understanding of the past. This case study of the discussion of 'Communist crimes' in the European Parliament has shown that the issue was put on the agenda by a small group of Central and Eastern European memory entrepreneurs who had managed to 'learn the ropes' of effective advocacy within the Assembly. An official vision of Communism then emerged through intense negotiations led by the two major political groups and structured by ideological and national lines of division.

The adoption of the Resolution on European Conscience and Totalitarianism provides three main insights into the functioning of the European Parliament. As regards uploading strategies, the negotiations over the wording of the document show that memory entrepreneurs need to adjust their rhetoric to the legitimate patterns of discourse of the chosen institution. This creates a tension between particularistic experiences and universal values, which is solved by referring to human rights and by embedding this narrative on Communism inside a laudatory account of European integration as the best way to overcome totalitarianism. Second, the successful adoption of the Resolution points to the benefits of uploading strategies during national controversies. The interpretation of the Communist past remains ideologically polarized throughout the former Eastern bloc, and the EP Resolution represents a symbolic advantage for Liberals and Conservatives on the Left in national political fields. Third, this official document signals that the marginalization of the 'newcomers' in the Assembly has been partly overcome, since they have managed to alter the hegemonic Western narrative on the common past of Europe by including the specific history of post-Communist Europe.

However, this 'totalitarian' conception of Communism remains to a certain extent of regional, rather than pan-European, relevance. Although the proclamation of 23 August as a day of 'Remembrance for the victims of all totalitarian and authoritarian regimes' and the creation of the Platform for European Memory and Conscience illustrate the self-assertion of post-communist states in the EU, the lack of symbolic resonance of these endeavors in Western or Southern European societies points to a persistent mnemonic fragmentation in Europe. In the competition for the definition of 'Europe' and its values, the persistent diversity in the assessment of Communism ultimately testifies to the local rootedness of remembrance despite the pan-European ambitions of memory entrepreneurs.

\section{References}

Batory, Agnes. 2014. "Uploading as Political Strategy: the European Parliament and the Hungarian media law debate". East European Politics 30(2): 230-245.

Beauvallet, Willy and Sébastien Michon. 2010. "La socialisation à l'Europe des élus européens - Acquisition et activation de dispositions à l'européanisation". In La fabrique 
des "Européens »: processus de socialisation et construction européenne, edited by Cécile Robert and Hélène Michel, 197-230. Strasbourg: Presses Universitaires de Strasbourg.

Beauvallet, Willy and Sébastien Michon. 2012. "Faire carrière au Parlement européen : activation de dispositions et socialisation institutionnelle". In Le champ de l'eurocratie. Une sociologie du personnel politique de l'UE, edited by Didier Georgakakis, 13-42. Paris: Economica.

Closa Montero, Carlos. 2010. "Study on How the Memory of Crimes Committed by Totalitarian Regimes in Europe is dealt with in the Member States". Madrid: Institute for Public Goods and Policy.

Closa Montero, Carlos. 2010. "Negotiating the Past: Claims for Recognition and Policies of Memory in the EU". Working Paper 08. Madrid: Instituto de Politicas y Bienes Publicos, CCHS-CSIC.

Costa, Olivier. 2000. Le Parlement européen, assemblée délibérante, Bruxelles : ULB.

Courtois, Stéphane and Nicolas Werth, Jean-Louis Panné, Karel Bartošek, Jean-Louis Margolin and Andrzej Paczkowski. 1997. Le livre noir du communisme. Crimes, terreur, répression. Paris : Robert Lafont.

EPP. 2004. "Resolution Adopted by the XVIth EEP Congress Condemning Totalitarian Communism".

EP. 2005. Resolution P6_TA(2005)0180 "The Sixtieth Anniversary of the End of the Second World War in Europe on 8 May 1945". Brussels: European Parliament.

EP. 2009a. Resolution P6_TA(2009)0213 "European Conscience and Totalitarianism". Brussels: European Parliament.

EPP. 2009b. "European Conscience and Totalitarianism (Debate)". Strasbourg: European Parliament.

EPP. 2009. "Motion for a Resolution on European conscience and totalitarianism" B60165/2009. Brussels: European Parliament.

European Commission. 2010. "The Memory of the Crimes Committed by Totalitarian Regimes in Europe". Report from the Commission to the European Parliament and to the Council, Brussels, COM(2010) 783.

European Council. 2008. "Framework Decision 2008/913/JHA on Combating Certain Forms and Expressions of Racism and Xenophobia by Means of Criminal Law". Brussels: European Council

European Council. 2007. "2794 ${ }^{\text {th }}$ Justice and Home Affairs Meeting 19-20 April 2007 Luxembourg Press Release Nr: 8364/07’'. Luxembourg: European Union Council.

Fassin, Didier, and Richard Rechtman. 2007. L'Empire du traumatisme: enquête sur la condition de victime. Paris: Flammarion.

Garcia, Patrick. 2009. "Vers une politique mémorielle européenne ? L'évolution du statut de l'histoire dans le discours du Conseil de l'Europe". Available at http://www.ihtp.cnrs.fr/sites/ihtp/IMG/pdf_Garcia_Vers_une_politique_memorielle_de_1 Europe 2009 .pdf

Georgakakis, Didier, ed. 2012. Le champ de l'eurocratie. Une sociologie du personnel politique de l'UE. Paris: Economica.

Hix Simon and Christopher Lord. 1997. Political parties in the European Union. Basingstoke: Palgrave Macmillan.

Hurka Steffen and Michael Kaeding. 2012. "Report allocation in the European Parliament after Enlargement". Journal of European Public Policy 19(4): 512-529.

Kalniete, Sandra. 2003. En escarpins dans les neiges de Sibérie. Paris: Editions des Syrtes.

Kauppi, Niilo. 2005. Democracy, Social Resources and Political Power in the European Union. Manchester: Manchester University Press. 
Knowlton, James and Truette Cates. 1993. Forever in the Shadow of Hitler? The Dispute about the German Understanding of History. Atlantic Highlands, NJ: Humanities Press.

Kopeček, Michal, ed. 2008. History in the making: Historical Revisionism in Central Europe since 1989. Budapest: Central European University Press.

Landsbergis, Vytautas. 2009. Un peuple sort de prison. Vilnius: UAB Baltijos kopija.

Leggewie, Claus. 2008. "A Tour of the Battleground: The Seven Circles of Pan-European Memory". Social Research 75: 217-234.

Littoz-Monnet, Annabelle. 2013. "Explaining Policy Conflict across Institutional Venues: European Union Struggles over the Memory of the Holocaust". Journal of Common Market Studies 51(3): 489-504.

Mälksoo, Maria. 2010. The politics of becoming European: a study of Polish and Baltic postCold War security imaginaries. London: Routledge.

Rowell, Jay and Michel Mangenot, eds. 2010, A Political Sociology of the European Union. Reassessing Constructivism. Manchester: Manchester University Press.

Mark, James. 2010. The Unfinished Revolution: Making Sense of the Communist Past in Central-Eastern Europe. New Haven: Yale University Press.

Mink, Georges, and Laure Neumayer, eds. 2013. History, Memory and Politics in East Central Europe. Memory Games. Houndsmills, Basingstoke: Palgrave Macmillan.

Neumayer, Laure. 2014. «Les politiques mémorielles européennes: légiférer sur le communisme au Parlement européen », paper presented at the conference « Le Parlement européen au travail », SAGE laboratory, Strasbourg, November 20-21.

PACE.1996. Resolution 1096 on "Measures to Dismantle the Heritage of Former Communist Totalitarian Systems". Strasbourg: Council of Europe.

PACE. 1992. Report 7209 on "Measures to dismantle the Communist totalitarian regimes". Strasbourg: Council of Europe.

PACE. 2006. Resolution 1481 on "The Need for International Condemnation of Crimes of Totalitarian Communist Regimes". Strasbourg: Council of Europe.

PES. 2009a. Politics of History: Uses and Abuses of the Past. Vienna: Renner Institute.

PES. 2009b. "Motion for a Resolution on European conscience and totalitarianism" B60164/2009. Brussels: European Parliament.

Pollak, Michael. 2000. L'expérience concentrationnaire : essais sur le maintien de l'identité sociale. Paris: Métailié.

Prague Declaration. 2008. "Declaration on European Conscience and Communism”. Prague.

Rostoks, Toms. 2011. "Debating 20th Century History in Europe: The European Parliament and the Parliamentary Assembly of the Council of Europe Compared", in The Geopolitics of History in Latvian-Russian Relations, 191-219. Riga: Academic Press of the University of Latvia,.

Rousso, Henry, ed. 1999. Stalinisme et nazisme: histoire et mémoire comparée. Brussels: Complexe.

Pakier, Małgorzata and Bo Stråth, eds. 2010. A European memory? Contested histories and politics of remembrance. New York: Berghahn Books.

Waehrens, Anne. 2011. "Shared Memories? Politics and Memory of Holocaust Remembrance in the European Parliament 1989-2009”, 6. DIIS Working Papers. Copenhagen: Danish Institute of International Studies. 
